\title{
Hurdles in starting laparoscopy in a rural medical college: our experience
}

\author{
Vijayata Sangwan*, Mukesh Sangwan, Sunita Siwach, Pinky Lakra, Rajiv Mahendroo, \\ Richa Kansal
}

Department of Obstetrics \& Gynaecology, BPS government medical college for women, Sonepat, Haryana, India

Received: 10 September 2015

Revised: 24 September 2015

Accepted: 07 October 2015

\author{
*Correspondence: \\ Dr. Vijayata Sangwan, \\ E-mail: vsangwan03@gmail.com
}

Copyright: () the author(s), publisher and licensee Medip Academy. This is an open-access article distributed under the terms of the Creative Commons Attribution Non-Commercial License, which permits unrestricted non-commercial use, distribution, and reproduction in any medium, provided the original work is properly cited.

\begin{abstract}
Background: Although laparoscopy surgery has certain proved advantages over open surgery like less scarring, less postoperative pain, early return to work etc. but has a long learning curve. The pressure of feeling we are behind as a surgeon if we don't embrace laparoscopy made us to take it on. With this paper we want to share our experiences i.e. beginner problem we faced, efforts and modification we adopted and current status of our journey. The aim of the study was to highlight the difficulties in starting laparoscopic surgeries and how to overcome them.

Methods: This is a retrospective study of all laparoscopic procedures performed in our newly established government medical college in rural India was started from 2013.

Results: We have performed cases of 27 diagnostic laparoscopy, 10 cases of laparoscopic ovarian cystectomy, 09 cases of ectopic pregnancy and cases of LAVH and 05 cases of TLH. Over a period of about two years out of total only 8 cases were performed in first year of study. It was our technical deficiency, nonavailability of mentor, anesthetists' reluctance for general anaesthesia due to prolonged duration of surgery and administrative pressure of long waiting list. To overcome these problems we underwent lap training with experts, attended CMEs, conferences and convinced anesthetists and administration for these surgeries. We also selected and trained our O.T. staff about technical demands of laparoscopy.

Conclusions: Start by doing what is necessary; then do whats possible and suddenly you are doing impossible. However conversion to open surgery should be kept at low threshold rather than landing yourself and patient in complications.
\end{abstract}

Keywords: Laparoscopy, Hysterectomy, Cystectomy

\section{INTRODUCTION}

The field of minimal invasive surgery has flowered explosively in recent past. It has revolutionized all surgical specialities all over the world. Laparoscopic surgery has gained ground due to its many advantages over laparotomy. To the patient avoidance of the discomfort of a large abdominal incision, reduction of postoperative pain and chances of wound complications, early mobilization and resumption of daily activities \& less adhesion formation. On the part of the surgeon improved visualisation offers better understanding of anatomy and surgery steps for assistants also. WHO also says "The enjoyment of the highest attainable standard of health is one of the fundamental rights of every human without distinction of race, religion, political belief, economic or social condition". Inspite of benefits and WHO statement availability of laparoscopic surgery is scarce in developing nations. In India about two third population is rural and one third of population is under poverty line have little access to this sophisticated mode of surgery2. However these people need it most as they have to work daily to earn bread \& butter. The cause for this scaricity is high cost for establishment and steep 
curve of learning laparoscopy. Considering all these facts and inspite of all our limitations lack of surgeons experience, untrained OT staff, limited instruments we started laparoscopy in our institute. With continuous practice on lap trainer and positive attitude we faced these issues resulting in 61 cases of successful laparoscopy.

The purpose of presenting our limited experience is to motivate beginners working in remote areas about wonderful art of laparoscopy so that our rural population may receive maximally benefit of this technique at their doorstep at affordable cost.

\section{METHODS}

This is a retrospective study conducted in the Department of Obstetrics \& Gynaecology from August 2013 to April 2015 in a newly established (September 2011) in rural setup. Patients were selected and investigated as in conventional open methods. Data was retrieved from case sheets of the patients and analysed. A written informed consent about the procedure and its conversion to open if needed was taken in each case. All patients were treated free of charge. Endobags were prepared from ADK drain packing available in government supply. Monopolar cautery, bipolar cautery and intracorporeal knotting was used for haemostasis vicryl 1-0 was used for vault repair. Duration of surgery stars with anaesthesia to skin closure including positioning and initial arrangements.

\section{RESULTS}

In the duration of 23 months we performed 454 open surgeries and 62 by laparoscopy, i.e.12\% of total surgeries. Observation of the study is presented below in tabular form.
Table 1: Distribution of cases according to age and procedure.

\begin{tabular}{|llll|}
\hline No. & $\begin{array}{l}\text { Surgical } \\
\text { procedures }\end{array}$ & $\begin{array}{l}\text { No\& } \% \text { of } \\
\text { surgeries }\end{array}$ & $\begin{array}{l}\text { Mean age } \\
\text { (year) }\end{array}$ \\
\hline 1 & $\begin{array}{l}\text { Dig. Lap for } \\
\text { infertility }\end{array}$ & $20(32.78)$ & 24.05 \\
\hline 2 & $\begin{array}{l}\text { Ovarian } \\
\text { cystectomy }\end{array}$ & $10(16.40)$ & 29.10 \\
\hline 3 & Ectopic preg & $09(14.75)$ & 26.33 \\
\hline 4 & LAVH & $09(14.75)$ & 46.22 \\
\hline 5 & $\begin{array}{l}\text { Diag. lap for Ch } \\
\text { pelvic pain }\end{array}$ & $07(11.47)$ & 32.71 \\
\hline 6 & TLH & $05(08.20)$ & 47.60 \\
\hline 7 & IUCD removal & $01(01.63)$ & 22 \\
\hline 8 & Total & 61 & 32.72 \\
\hline
\end{tabular}

Table 1 shows number of different surgeries conducted and mean age at the time of surgery. Diagnostic laparoscopy for infertility was the first case conducted by us. In ovarian cystectomy the cyst size varies from 7-8 $\mathrm{cm}$ to $28-30 \mathrm{~cm}$. The mean age of the whole study group was 32.72 yrs.

Table 2 depicts slow increase in total number of surgeries with the passage of time. Average time of surgeries along with a range of maximum to minimum time in minutes is given. In the beginning laparoscopy was utilized for diagnostic procedures only and slowly operative procedures were also attempted successfully. Total duration of surgery was also on falling trend since beginning.

Table 2: Progress in laparoscopy in terms of no. and duration of surgery.

\begin{tabular}{|lllll|} 
& $\begin{array}{l}\text { Aug-Dec 2013 } \\
\text { (5mnths) }\end{array}$ & $\begin{array}{l}\mathbf{2 0 1 4} \\
(\mathbf{1 2} \text { mnths) }\end{array}$ & $\begin{array}{l}\text { Jan-June 2015 } \\
(6 m n \text { ths) }\end{array}$ & $\begin{array}{l}\text { Avg. time of surgery in } \\
\text { minutes (with max.\& min) }\end{array}$ \\
\hline Dig. Lap for infertility (20) & 02 & 11 & 07 & $80.52(140-45)$ \\
\hline Ovarian cystectomy (10) & 01 & 06 & 03 & $92.20(160-45)$ \\
\hline Ectopic pregnancy (09) & 01 & 05 & 03 & $94.43(180-60)$ \\
\hline LAVH (09) & 00 & 06 & 03 & $140.6(180-120)$ \\
\hline Diag. lap for Ch. pelvic pain (07) & 01 & 03 & 03 & $88.00(140-80)$ \\
\hline TLH (05) & 0 & 02 & 03 & $186.42(200-160)$ \\
\hline IUCD Removal (1) & 0 & 0 & 01 & 60 \\
\hline Total (61) & 05 & 33 & 23 & \\
\hline
\end{tabular}

Table 3 depicts the number of conversions and cause. The first cause is adhesions and second cause was inability to achieve haemostasis. The two cases of ovarian cystectomy were post hysterectomy ovarian cysts and adhesions present between the cyst, gut and lateral wall. On open surgery ureter was found in close relation to cyst. The case of ectopic pregnancy was a chronic ectopic pregnancy case having 7-8 cm mass with clots involving left side broad ligament, adnexa and lateral wall.

The two cases of chronic pelvic pain were intraoperatively found to have bilateral tuboovarian mass 
with pus. In hysterectomy cases it was bleeding that caused conversion. One case of LAVH was opened abdominally and procedure completed. Two cases of TLH were converted to TAH and LAVH for inability to achieve haemostasis.

Intraoperative complications include development of subcutaneous emphysema in two cases. Postoperative complications include subacute intestinal obstruction in two cases (1infertility \& 1 chronic pelvic pain) relieved conservatively. Both the cases had history of intake of antitubercular drugs.

This table shows our surgical load of patients. Lap surgeries constitute $12 \%$ of total surgeries.

Table 3: Progress of learning lap.

\begin{tabular}{|llll|}
\hline & $\begin{array}{l}\text { No. of cases } \\
\text { converted }\end{array}$ & Cause for conversion & Avg. hospital stay (days) \\
\hline $\begin{array}{l}\text { Dig. Lap for } \\
\text { infertility (20) }\end{array}$ & -- & -- & 1.9 \\
\hline $\begin{array}{l}\text { Ovarian cystectomy } \\
(10)\end{array}$ & 02 & $\begin{array}{l}\text { Dense adhesions between cyst gut and } \\
\text { lateral wall }\end{array}$ & 1.4 (8 days in laparotomy pts. \\
\hline Ectopic preg (09) & 01 & $\begin{array}{l}\text { Ch. Ectopic haemostasis could not } \\
\text { achieved }\end{array}$ & 1.3 (5days in laparotomy patient) \\
\hline LAVH (09) & 01 & Excessive bleeding & $\begin{array}{l}5.0 \text { (as delayed bowel sounds were } \\
\text { there) }\end{array}$ \\
\hline $\begin{array}{l}\text { Diag. lap for Ch } \\
\text { pevlic pain (07) }\end{array}$ & 02 & To mass with dense adhesions & 2.2 (10-12 days in laparotomy case) \\
\hline TLH (05) & 02 & 1 converted to LAVH and one open & $\begin{array}{l}6.4 \text { (as delayed bowel sounds were } \\
\text { there) }\end{array}$ \\
\hline IUCD removal (1) & -- & -- & 1.0 \\
\hline Total (61) & 08 & -- & -- \\
\hline
\end{tabular}

Table 4: Other surgeries performed in the same time period.

\begin{tabular}{|lllll|}
\hline Surgeries performed & $\begin{array}{l}\text { Aug-Dec 2013 } \\
\text { (05mnths) }\end{array}$ & $\begin{array}{l}\text { Jan-Dec 2014 } \\
(12 \text { mnths) }\end{array}$ & $\begin{array}{l}\text { Jan-May 2015 } \\
\text { (5mnths) }\end{array}$ & $\begin{array}{l}\text { Total } \\
173\end{array}$ \\
\hline Vaginal hysterectomy with repair & 29 & 102 & 06 & 32 \\
\hline Conservative surgery for prolapse & 06 & 20 & 159 \\
\hline $\begin{array}{l}\text { Abdominal hysterectomy with or } \\
\text { without BSO }\end{array}$ & $\begin{array}{l}35 \text { (Uterine size more } \\
\text { than 14 week in 28 } \\
\text { cases) }\end{array}$ & $\begin{array}{l}\text { 92 (Uterine size } \\
\text { more than 14 week } \\
78 \text { cases) }\end{array}$ & 32 & 31 \\
\hline $\begin{array}{l}\text { Laparotomy for ovarian cyst } \\
\text { (benign \& malignant) }\end{array}$ & 05 & 19 & 07 & 35 \\
\hline Recanalization & 02 & 25 & 08 & 16 \\
\hline NDVH & 02 & 07 & 07 & 08 \\
\hline Others & 3 & 05 & 00 & 454 \\
\hline Total cases & 82 & 270 & $23(18.4 \%)$ & 62 \\
\hline Lap cases & $05(6 \%)$ & $33(11 \%)$ & & 32 \\
\hline
\end{tabular}

\section{DISCUSSION}

Advancement in operative technique is an on-going process over the decades with a spark in recent past by introduction of laparoscopy. Surgeons all over the world are striving hard to embark on the voyage of laparoscopy surgery. We started our journey with diagnostic cases in
Aug 2013. Out of total 515 only 61 cases (12\%) were operated laparoscopically in our study, Nasir et. al. reported $7.4 \%$ cases, $23.7 \%$ by Badejoko et al, 3.4\% Yakasai et al and 78 cases in 4 yr by Dhaliwal et al from Baharin. ${ }^{3-6}$ This shows that in developing countries still open surgery is predominant and laparoscopy is in its evolutionary phase. However diagnostic and operative 
laparoscopy made its way long back in western world in 1960 and 70s when Dr. Kurt Semm advocated laparoscopy in infertility patients. ${ }^{5}$ With the introduction of video camera for in 1982 there was a big boon in endoscopic surgeries and now it has become a standard approach for almost all the gynaecological procedures along with gyane oncology also.

Table 5: The duration of surgery of the present study was compared with other studies.

\begin{tabular}{|lll|}
\hline $\begin{array}{l}\text { Type of } \\
\text { surgeries }\end{array}$ & $\begin{array}{l}\text { Duration of } \\
\text { surgery in } \\
\text { present study }\end{array}$ & $\begin{array}{l}\text { Duration of } \\
\text { surgery by } \\
\text { Sushan et. al. }\end{array}$ \\
\hline $\begin{array}{l}\text { Dig. Lap for } \\
\text { infertility (20) }\end{array}$ & $80.52(140-45)$ & $60.2(15-240$ \\
\hline $\begin{array}{l}\text { Ovarian } \\
\text { cystectomy } \\
(10)\end{array}$ & $92.20(160-45)$ & $74.3(10-240)$ \\
\hline $\begin{array}{l}\text { Ectopic preg } \\
\text { (09) }\end{array}$ & $94.43(180-60)$ & $55.9(13-140)$ \\
\hline $\begin{array}{l}\text { LAVH (09) } \\
140.6(180-120)\end{array}$ & $131.1(30-400)$ \\
\hline $\begin{array}{l}\text { Diag. lap for } \\
\text { Ch pevlic pain } \\
(07)\end{array}$ & $88.00(140-80)$ & $69.5(10-180)$ \\
\hline TLH (05) & $\begin{array}{l}186.42(200- \\
160)\end{array}$ \\
\hline
\end{tabular}

In developing countries like India, private institutions are far ahead than government hospital in this art of surgery. There is huge disparity in laparoscopic surgeries between public and private health institutions in developing nations, higher level of endoscopy are done mainly in private setups 5 . The reasons may be lack of technical support like required instruments and energy sources, a poor coordinative environment between specialities, and scaricity of mentors in government centres. The faculty of majority government institutes is still in learning phase. There is huge deficiency of established public teaching hospitals with specialised gynaecological endoscopy units that could serve as teaching hub for beginners.

Due to high incidence of poverty, government hospitals are already overburdened, analysis of literature suggest that in developing countries uterovaginal prolapse is most common indication of hysterectomy followed by CIN and fibroid uterus ${ }^{7}$. In the present study also $45.15 \%$ patients were operated for prolapse, and $35.02 \%$ for fibroid uterus with or without AUB. Huge load of patients, limited OT day, results in long waiting lists for patients. Moreover due to high proportion of uterovaginal prolapse cases $(45 \%)$ where vaginal hysterectomy is indicated, and cases for laparoscopic surgeries are relatively limited. In the beginning smart case selection is important as failure or complication in learning phase downs the morale.

Majority patients $(43.25 \%)$ in present study were for diagnostic purpose including infertility and chronic pelvic pain followed by hysterectomy $(22.95 \%)$, ovarian cystectomy (16.40\%) and ectopic pregnancy (14.75\%). Yakasai IA et al reported $99 \%$ diagnostic cases in their beginning work, Condos $\mathrm{P}$ in their study also used laparoscopy for diagnostic purpose mainly, Nasir et al also reported diagnostic laparoscopy for infertility as most commonly performed procedure. ${ }^{3,5,8}$ Beginners should start with diagnostic procedure, this helps in overcoming oneself inhibition and fear of starting a new thing, improves knowledge of instrument handling, helps in getting well versed with clicks of veress needle. It also helps in understanding pelvic anatomy and developing a trained team.

No major complications have been noticed in our study, incidence of minor complications in present study was $3.2 \% .^{3-6}$ Other studies as mentioned above also reported no major complication The reason may be the dominance of diagnostic procedures in all the studies and low threshold for conversion to open. Major complications especially in the learning phase not only break the morale of team but can be life threatening to the patient as well.

Babu GS et al reported an average time of 80-320 min in their study and Badezko OO et al reported it 33-185 min. ${ }^{2,4}$ In the present study the probable reasons for prolong duration include poor hand eye coordination, fogging of lens, untrained camera assistant, difficulty in retrieval of tissue after surgery, difficulty in choosing right instruments during surgery. Initially positioning of patient, allocating positions to assistants, and doing connection of cable used to take more time than surgery itself.

Average duration of hospital stay was 1.2 to 2.2 days in patients of diagnostic laparoscopic surgeries and 6-7 days in hysterectomy cases. Studies by beginners also reported 2-6 days and $4 \mathrm{hr}$ to 5 days comparable hospital stay. ${ }^{2,4}$ No major postoperative complication were reported in the studies same in our study may be because less advanced operative work and early conversion. ${ }^{3-6}$

Laparoscopic surgery is a hybrid surgical approach requiring good technical support and expertise of surgeon. An experienced surgeon can bear with any instrument but a beginner needs a good set of proper instrument. In government centres the expertise of surgeons lacks and modern instruments like harmonic scalpel, uterine manipulators, and morcellators are not available. With progressive experience and skill of endosuturing and knotting we are switching over from open to lap procedures at our center. In 2013, 6.1\% of total surgeries were performed with laparoscopy, the figure moves on to $11 \%$ and $18.4 \%$ in 2014 \& 2015. Duration of surgery also reduced as shown in table 3 .

Different studies are there to assess the learning process of laparoscopy, in few studies CUSUM curve or Cumulative model is used to assess trends in multiple surgical outcomes and learning curve for laparoscopic 
surgeries. ${ }^{10} \mathrm{~A}$ few studies gives a minimum number of cases necessary to perform to attain surgical proficiency, Rasen MBD et al reported 10 supervised cases by trainee helps him to achieve plateau and after performing 16 supervised cases duration of surgery starts decreasing. ${ }^{11}$ Ravikanth GO et. al. ${ }^{12}$ found a minimum of 70 cases need to be performed to improve surgical proficiency. We are not much experienced to give a minimum number of surgeries, but definitely practice makes a man perfect.

Lesson learnt by us in our journey: a hardworking, calm and quiet attitude with persistent strong drive for improvement, understanding anaesthetist, trained team, good knowledge of instruments and belief in GOD are the requirements for doing good endoscopic surgery. In the beginning smart selection of cases and low threshold for conversion is required for the safety of patient as well as surgeon.

Funding: No funding sources Conflict of interest: None declared

Ethical approval: The study was approved by the Institutional Ethics Committee

\section{REFERENCES}

1. WHO (2005) Estimates of health problems.

2. Babu GS, Sujatha VV. Adoption of laparoscopy in a rural medical college hospital: minimal access surgery for masses a reality. J Womens Health, Issues Care. 2013;2(4):1-4.

3. Nasir S, Hassan M, Tanau K, Abubakar PA, Ahmed Y, Umar AG. Experience with gynaecological laparoscopy in a tertiary hospital, North-West Nigeria. Journal Home. 2014;26(1-2).

4. Badejko OO, Adeyemi AB, Kuti O, Ijarotimi O, Loto OM, Awowole IO. Operative gynecologic laparoscopy in Ile-Ife, Nigeria: Preliminary experience. Journal of Gynecologic Surgery. African journal Online. 2013;29(4):186-9.
5. Yakasi IA, Abdullahi J, Omole-Ohonsi A, Ibrahim SA. Gynaecologic laparoscopy at Aminu Kano Teaching Hospital, kano,Nigeria : a 5 yr review. British Journal of Science. 2012;5(1):11-7.

6. Dhaliwal JK, Shaefi AA, Sharqi MA. Laparoscopic surgery in gynaecology -Salmaniya experience. Bahrain Medical Bulletin. 2000;22(4):1-8.

7. Renjhen $\mathrm{P}$, Behura S, Acharya S. Trends in hysterectomy for benign causes: a retrospective study at Kohalapur Teaching Hospital. Journal of Nepal Medical Association. 2003;42(147):156-9.

8. Condos P. Experience with gynaecological laparoscopy. Australian and NewZealand Journal of Obstetrics and Gynecology. 1972;12(3)188-93.

9. Sushan A, Mohamed H, Magos AL. How long laparoscopic surgery does really takes? Lessons learnt from 1000 laparoscopies. Human Reproduction. 1999;14(1):39-43.

10. Barrie J, Jayne DG, Wright J, Murray CJ, Collinson FJ, Pavitt SH. Attaining surgical competency and its implications in surgical clinical trial design: a systematic review of the learning curve in laparoscopic and robot-assisted laparoscopic colorectal cancer surgery. Ann Surg Oncol. 2014;21(3):829-40.

11. Rosen MBD, Cario GM, Carlton MA, Lam AM, Chapman A. An assessment of the learning curve for laparoscopic and total laparoscopic hysterectomy. Gynecology Endoscopy. 1998;7(6):289-93.

12. Ravikanth GO, Deepa JG, More S, Gandham S, Munaganur N. Evaluation of the learning curve in Total laparoscopic hysterectomy. Int. Journal of Biomedical Research. 2014;5(1):732-5.

Cite this article as: Sangwan V, Sangwan M,

Siwach S, Lakra P. Hurdles in starting laparoscopy in a rural medical college: our experience. Int J Reprod Contracept Obstet Gynecol 2015;4:1858-62. 